\title{
Bioavailable dissolved organic phosphorus and phosphorus use by heterotrophic bacteria
}

\author{
Monika Nausch*, Günther Nausch \\ Baltic Sea Research Institute Warnemünde, Seestrasse 15, 18119 Rostock-Warnemünde, Germany
}

\begin{abstract}
Dissolved organic phosphorus (DOP) concentrations were measured in surface water at 3 stations in the central Baltic Sea from May to July 2005. The amount of bioavailable DOP (BAP) was estimated in time course experiments using $0.8 \mu \mathrm{m}$ filtered seawater and carbon plus nitrogen additions with the aim of verifying results obtained in 2004. The consumption of dissolved inorganic phosphorus (DIP) and DOP by heterotrophic bacteria under natural water conditions was determined in parallel experiments without any substrate amendment. In both years, most DOP and BAP concentrations were in the same range of between 0.20 and $0.31 \mu \mathrm{M}$, and 0.04 and $0.12 \mu \mathrm{M}$, respectively, with a tendency to decline from spring to summer. BAP constituted a proportion of 33.2 to $60.0 \%$ of DOP. Bacterial phosphorus use differed between the Gotland and Bornholm Basins. In the eastern and south-eastern Gotland Basin, DIP was taken up completely, independently from initial concentrations in substrate addition experiments. Without any substrate addition, less DIP was used in May. In subsequent investigations in June and July, the DIP was taken up in full. Under natural conditions, the uptake of BAP ranged between 18 and $78 \%$ and reached $100 \%$ in summer when heterocystous cyanobacteria occurred in surface water. In the Bornholm Basin, all the BAP was used in July despite the availability of DIP. These results indicate that the phosphorus uptake in both basins may be carbon and/or nitrogen limited in May. The limitation was repressed in summer in the Gotland Basin, but was sustained in the Bornholm Basin. Thus, the BAP use could satisfy the carbon demand in the Bornholm Basin, whereas it fulfils the phosphorus demand in the Gotland Basin.
\end{abstract}

KEY WORDS: Phosphorus · DOP · DIP · Bioavailable dissolved organic phosphorus · Bacteria · Baltic Sea

Resale or republication not permitted without written consent of the publisher

\section{INTRODUCTION}

Carbon, nitrogen, and phosphorus are the principal nutrients sustaining phytoplankton and bacterial growth. Because of its low concentration compared to nitrogen, phosphorus is often the limiting nutrient in fresh water ecosystems. In marine ecosystems, phosphorus becomes limiting if nitrogen deficiency is compensated by nitrogen fixation. Phosphorus is usable for plankton nutrition only in dissolved form: dissolved inorganic phosphorus (DIP) and dissolved organic phosphorus (DOP). While DIP, as an essential nutrient for phytoplankton and bacterial growth, was never under discussion, the importance of DOP as a relevant $P$ source was not clear for a long time and is still not fully clarified. The first attempts to measure DOP con- centrations in natural waters were in the 1930s and 1940s (Kalle 1933, Robinson 1941). DOP as a potential phosphorus source was first reported by Newcombe \& Brust (1940) and Chu (1946), and 20 to 30 yr later by e.g. Johannes (1964) and Minear (1972). Nevertheless, Heath (1986) noticed, for freshwater systems, that the detailed function of DOP as a significant phosphorus source was unknown, a fact that could also be applied to the ocean. Since that time, there have been many efforts to elucidate the distribution, biochemical function, and behaviour of DOP in freshwater and marine systems. Many reports deal with the quantitative distribution of DOP (Karl \& Björkman 2002, Suzumura \& Ingall 2004, Yoshimura et al. 2007). Size classes of DOP have been described (e.g. Matsuda et al. 1985, Cooper et al. 1991) and attempts made to describe the bio- 
chemical compounds (Strickland \& Solorzano 1966, DeFlaun et al. 1987). Phosphorus-containing substrates in water are nucleic acids (DNA, RNA), nucleotides (ATP), and phospholipids. Sannigrahi et al. (2006) found in ultra-filtered dissolved organic matter of marine waters that phosphorus was associated with carbohydrates, amino acids, and lipids. The biochemical binding of phosphorus to the organic molecule is as phosphoesters (mono- and diesters), which may be produced predominantly autochthonously by exudation, decomposition, and autolysis of organisms and may be preferentially bioavailable (Benitez-Nelson \& Buesseler 1999). Another group, the phosphonates, have been identified as a significant constituent of DOP in marine waters (Monaghan \& Ruttenberg 1999, Kolowith et al. 2001) and are believed to be less bioavailable (Dyhrman et al. 2006). Bioavailable dissolved organic phosphorus (BAP) is that part of DOP that can be taken up by organisms directly or after enzymatic degradation. It amounts to $7-25 \%$ of the total DOP in the North Pacific Subtropical Gyre (Björkman \& Karl 2003), to 55.2-65.4\% in the productive surface layer of the central Baltic Sea (Nausch \& Nausch 2006), and 5-14\% in Lough Neagh (Northern Ireland) (Cooper et al. 1991).

Despite increasing knowledge about DOP in the past 2 or 3 decades, there is still a lack in understanding of the biogeochemistry and cycling of DOP in aquatic ecosystems. Thus, in the Baltic Sea, investigations of phosphorus were directed mainly into the spatial and temporal variability of DIP. First, DIP concentrations were measured in the 1930s (Kalle 1932, Wattenberg \& Meyer 1936) and much more regularly within the past 40 yr (HELCOM 1980). Nehring \& Brügmann (1977) measured organically bound phosphorus in the Baltic Sea but did not differentiate between dissolved and particulate organic phosphorus forms. DOP concentrations have been detected since 1999 (Põder et al. 2003). Recently, the bioavailability of DOP was studied by Stepanauskas et al. (2002) in rivers entering the Baltic Sea and by Nausch \& Nausch (2006) in the central Baltic Sea in summer 2004. We continued our investigations in the central Baltic Sea in 2005 with the following aims: (1) to verify the results of bioavailable DOP obtained in 2004, (2) to check that the method used is able to detect all the bioavailable DOP, and (3) to estimate the amount of BAP used by heterotrophic bacteria in situ.

\section{MATERIALS AND METHODS}

Water sampling and hydrographic conditions. Experiments were conducted during 4 cruises in May, June, and July 2005 with the RVs 'Gauss' and 'Prof. Albrecht Penck' in the central Baltic Sea, at Stn 213 $\left(55^{\circ} 14.9^{\prime} \mathrm{N}, 15^{\circ} 58.9^{\prime} \mathrm{E}\right)$ in the Bornholm Basin, Stn 259 $\left(55^{\circ} 33.0^{\prime} \mathrm{N}, 18^{\circ} 23.9^{\prime} \mathrm{E}\right)$ in the south-eastern Gotland Basin and Stn 271 (57 $\left.19.2^{\prime} \mathrm{N}, 20^{\circ} 03.05^{\prime} \mathrm{E}\right)$ in the eastern Gotland Basin (Fig. 1). Samples (1 to $2 \mathrm{~m}$ depth) were taken using a rosette sampler (Hydrobios) combined with a Seabird SBE 911 probe equipped with sensors for conductivity, temperature, and salinity. Temperature, salinity, and chemical and biological parameters characterizing the conditions during water sampling are given in Table 1.

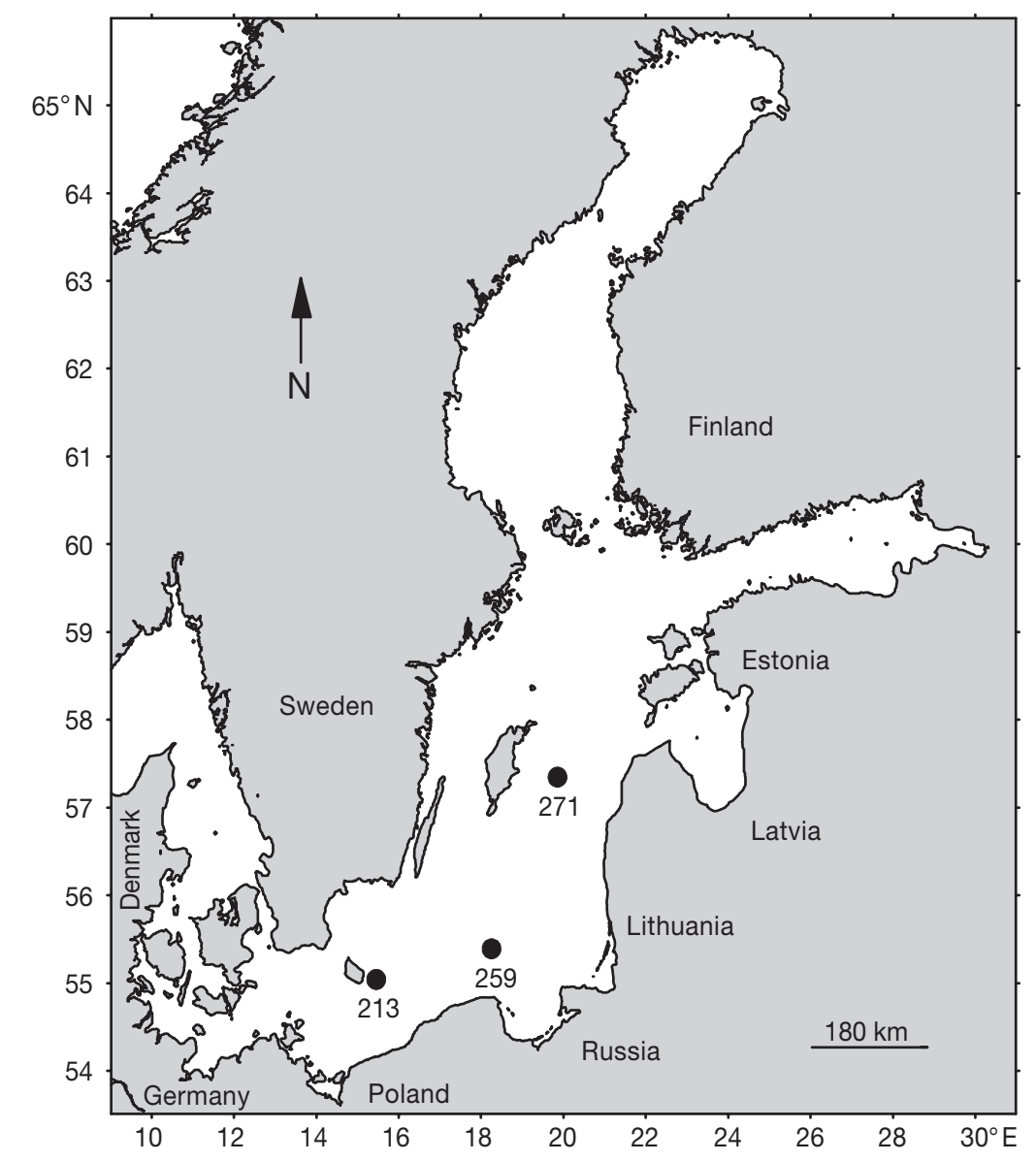

Fig. 1. Sampling stations in the central Baltic Sea: Stn 271 is located in the eastern Gotland Basin, Stn 259 in the southeastern Gotland Basin, and Stn 213 in the Bornholm Basin 
Table 1. Hydrographical, chemical and biological conditions during water sampling for experiments conducted in 2005 to detect bioavailable dissolved phosphorus. $\mathrm{TP}=$ total (dissolved + particulate) phosphorus; DIP = dissolved inorganic phosphorus; $\mathrm{DOP}=$ dissolved organic phosphorus; TDP = total dissolved phosphorus; $\mathrm{ww}=$ wet weight

\begin{tabular}{|c|c|c|c|c|c|c|c|c|c|c|c|c|c|}
\hline Stn & Date & $\begin{array}{c}\text { Temp. } \\
\left({ }^{\circ} \mathrm{C}\right)\end{array}$ & Salinity & $\begin{array}{c}\mathrm{NO}_{2 / 3} \\
(\mu \mathrm{M})\end{array}$ & $\begin{array}{l}\mathrm{NH}_{4} \\
(\mu \mathrm{M})\end{array}$ & $\begin{array}{l}\text { TP } \\
(\mu \mathrm{M})\end{array}$ & $\begin{array}{l}\text { DIP } \\
(\mu \mathrm{M})\end{array}$ & $\begin{array}{l}\text { DOP } \\
(\mu \mathrm{M})\end{array}$ & $\begin{array}{l}\text { TDP } \\
(\mu \mathrm{M})\end{array}$ & $\begin{array}{c}\mathrm{Chl} a \\
\left(\mu \mathrm{g} \mathrm{l}^{-1}\right)\end{array}$ & $\begin{array}{c}\text { Heterotrophic } \\
\text { bacteria } \\
\left(\times 10^{6} \mathrm{ml}^{-1}\right)\end{array}$ & $\begin{array}{l}\text { Heterocystous } \\
\text { cyanobacteria } \\
\left(\mathrm{ww}, \mathrm{mg} \mathrm{m}^{-3}\right)\end{array}$ & $\begin{array}{c}\text { Other } \\
\text { autotrophs } \\
\left(\mathrm{ww}, \mathrm{mg} \mathrm{m}^{-3}\right)\end{array}$ \\
\hline \multirow[t]{4}{*}{213} & 13 May & 7.89 & 7.62 & 0.02 & 0.15 & 1.07 & 0.60 & 0.31 & 0.91 & 1.22 & 0.78 & 13.2 & 298.0 \\
\hline & 11 June & 10.94 & 7.60 & 0.03 & 0.23 & 0.89 & 0.47 & 0.23 & 0.70 & 1.25 & 3.72 & 0.1 & 308.8 \\
\hline & 6 July & 16.37 & 7.55 & 0.04 & 0.17 & 1.53 & 0.38 & 0.26 & 0.64 & 1.28 & 3.20 & 19.7 & 225.1 \\
\hline & 22 July & 17.79 & 7.55 & 0.09 & 0.11 & 1.00 & 0.27 & 0.29 & 0.56 & 1.95 & 6.07 & 10.9 & 345.6 \\
\hline \multirow[t]{4}{*}{259} & 14 May & 8.15 & 7.37 & 0.06 & 0.20 & 1.00 & 0.13 & 0.30 & 0.43 & 4.36 & 6.50 & 35.5 & 1028.1 \\
\hline & 12 June & 10.60 & 7.36 & 0.09 & 0.19 & 0.69 & 0.22 & 0.29 & 0.50 & 1.96 & 2.78 & 27.1 & 309.0 \\
\hline & 7 July & 18.21 & 7.36 & 0.02 & 0.17 & 0.56 & 0.06 & 0.21 & 0.27 & 4.21 & 8.20 & 593.1 & 486.6 \\
\hline & 23 July & 17.24 & 7.38 & 0.10 & 0.13 & 0.64 & 0.12 & 0.20 & 0.32 & 4.70 & 5.88 & 1607.6 & 795.7 \\
\hline \multirow[t]{4}{*}{271} & 15 May & 6.84 & 7.27 & 0.02 & 0.13 & 0.67 & 0.12 & 0.28 & 0.40 & 2.20 & 1.27 & 11.8 & 742.6 \\
\hline & 13 June & 11.14 & 7.17 & 0.04 & 0.24 & 0.56 & 0.00 & 0.27 & 0.27 & 3.18 & 3.85 & 67.1 & 574.3 \\
\hline & 8 July & 18.98 & 7.12 & 0.05 & 0.19 & 0.52 & 0.00 & 0.22 & 0.22 & 14.97 & 7.40 & 4514.9 & 3039.4 \\
\hline & 25 July & 16.92 & 6.91 & 0.00 & 0.25 & 0.60 & 0.04 & 0.21 & 0.25 & 4.86 & 9.16 & 184.2 & 803.4 \\
\hline
\end{tabular}

Experimental layout. For the determination of BAP and the bacterial utilization of DOP, water was filtered through $0.8 \mu \mathrm{m}$ cellulose nitrate filters (Whatman) immediately after sampling using a vacuum of -200 mbar to obtain water without phyto- or zooplankton but containing free-living heterotrophic bacteria. The filters were pre-rinsed with MilliQ water. The filtrate was poured into 4 sterilized Duran bottles cleaned with $1 \mathrm{M}$ $\mathrm{HCl}$ and MilliQ water. Each bottle contained 5.51 filtered seawater. For the determination of BAP, ammonium chloride $(7 \mu \mathrm{M})$ and $\mathrm{D}-(+)$-glucosemonohydrate $\left(1 \mathrm{mg} \mathrm{l}^{-1}\right.$ ) were added to 2 bottles to prevent nitrogen and carbon limitation. The 2 remaining bottles were left without any additions to investigate the phosphorus uptake under natural nutrient conditions. All bottles were incubated in the dark at in situ temperatures and aerated with air passed through a $0.2 \mu \mathrm{m}$ filter. During an incubation time of 6 or $7 \mathrm{~d}$, daily sub-samples were taken to determine inorganic nutrients, DOP, and bacterial abundances.

To verify whether the same amount of BAP is obtained if other organisms are used in the experiments, DOP uptake by cyanobacteria was studied in parallel experiments done at Stn 271 in the eastern Gotland Basin. Water was first filtered through precombusted GF/F filters and then through a $0.2 \mu \mathrm{m}$ tangential filtration system (Vivaflow), and 5.51 was bottled in pre-cleaned Duran bottles. Nodularia harveijana grown in F/2 medium was separated from the medium by filtration onto $5 \mu \mathrm{m}$ polycarbonate filters and washed with $0.2 \mu \mathrm{m}$ filtered seawater. Suspended Nodularia was added to $0.2 \mu \mathrm{m}$ filtered water in the Duran bottles at chl a concentrations of 2.6 to 3.8 $\mu \mathrm{g} \mathrm{l}^{-1}$, aerated, and incubated in a light:dark cycle of 16:9 h for 6 d. Experiments were conducted in dupli- cate. Similarly to the experiments above, sub-samples for the determination of inorganic nutrients and DOP were taken daily.

Analytical methods. After sub-sampling, DIP and ammonium were analysed manually using standard colorimetric methods (Grasshoff et al. 1983). The sum of nitrate and nitrite $\left(\mathrm{NO}_{2 / 3}\right)$ was measured in an autoanalyser system (Evolution III) after filtration through pre-rinsed $0.2 \mu \mathrm{m}$ cellulose acetate filters in experiments with heterotrophic bacteria or after filtration through GF/F filters in the experiments with Nodularia using the same colorimetric methods. The detection limit was $0.02 \mu \mathrm{M}$ for DIP, $0.05 \mu \mathrm{M}$ for ammonium, and $0.05 \mu \mathrm{M}$ for $\mathrm{NO}_{2 / 3}$.

For the determination of DOP, $40 \mathrm{ml}$ of water was filtered through a $0.2 \mu \mathrm{m}$ cellulose acetate filter and stored at $-20^{\circ} \mathrm{C}$ until further processing. The thawed samples were oxidized with potassium peroxidisulfate in an alkaline medium (Grasshoff et al. 1983). The subsequent DIP determination was done using a $10 \mathrm{~cm}$ cuvette reaching a detection limit of $0.01 \mu \mathrm{M}$. Measurements were made in duplicate from each incubation bottle. DOP was calculated as the difference between the total P concentration in the $0.2 \mu \mathrm{m}$ filtered water and the corresponding DIP concentration.

BAP is derived from enrichment experiments as the difference between DOP concentrations at the start and the lowest DOP concentrations during the incubation. The remaining DOP is called the 'refractory' fraction. The same approach was applied in the other types of experiments to estimate the consumed BAP.

Chlorophyll a was analysed fluorometrically with a Turner fluorometer. Water samples were filtered on Whatman GF/F filters and the filters were stored in liquid nitrogen on board and afterwards in the laboratory at $-80^{\circ} \mathrm{C}$. Thawed filters were extracted with $96 \%$ 
ethanol for at least $4 \mathrm{~h}$. Fluorescence was measured at an excitation of $450 \mathrm{~nm}$ and an emission of $670 \mathrm{~nm}$ (HELCOM 2001).

Phytoplankton composition and bio-volumes were determined according to the HELCOM guidelines (HELCOM 1988). Samples preserved with acetic Lugol solution $\left(\mathrm{KI} / \mathrm{I}_{2}\right)$ were counted under an inverted microscope (Axiovert, Leica). The cell volume was calculated from the size measurements by using the appropriate stereometric formula. It was converted to wet weight $\left(\mathrm{ww}, \mathrm{mg} \mathrm{m}^{-3}\right.$ ), assuming that the density of the plasma is equal to that of water (approximately $1 \mathrm{mg} \mathrm{mm}^{-3}$ ).

The enumeration of bacteria was done using the flow cytometer 'FacsCalibur' (Becton Dickinson). Following the method of Gasol \& del Giorgio (2000), $4 \mathrm{ml}$ samples were preserved with $50 \mu \mathrm{l}$ formaldehyde $(0.5 \% \mathrm{v} / \mathrm{v}$ final concentration), shock frozen in liquid nitrogen, and stored at $-80^{\circ} \mathrm{C}$ until measurement. Bacteria were stained with SYTO-13 (Molecular Probes) at a final concentration of $5 \mu \mathrm{M}$. After addition of fluoresbrite microspheres (Polysciences), measurements were performed at a low flow rate. Measurements and calculations were done using the software program 'Cell Quest Pro' (Becton Dickinson).

Statistical calculations were done using the computer software program 'Statistica 6'.

\section{RESULTS}

\section{Nutrient and microplankton concentrations during water sampling}

From May to July 2005, inorganic nitrogen compounds in the surface water were in the typical concentration range for the transition period from spring to summer. The development of DIP, however, varied between the basins, a phenomenon first observed in 2004 (Nausch et al. 2005). In all locations, mean ( \pm SD) inorganic nitrogen concentrations with $\mathrm{NO}_{2 / 3}$ values of $0.05 \pm 0.04 \mu \mathrm{M}$ (Table 1 ) and $\mathrm{NH}_{4}$ values of $0.18 \pm$ $0.05 \mu \mathrm{M}$ were at or near to the detection limit, indicating that the winter inorganic nitrogen reservoir of 3 to $4 \mu \mathrm{M}$ (Nausch et al. 2006) was consumed completely by the phytoplankton spring bloom.

In contrast, remarkable DIP concentrations remained in May with large differences between the stations: values of $0.60,0.13$, and $0.12 \mu \mathrm{M}$ were measured at Stns 213, 259, and 271, respectively. DIP was completely consumed in the eastern Gotland Basin (Stn 271) by mid-June and remained near the detection limit subsequently. In the southern Gotland Basin (Stn 259), fluctuations in DIP concentrations were observed; the concentration increased from May to June by $0.10 \mu \mathrm{M}$, then dropped to $0.06 \mu \mathrm{M}$ in the first half of July and increased again to $0.12 \mu \mathrm{M}$ in the second half of July. At Stn 213 in the Bornholm Basin, DIP concentrations decreased by $0.33 \mu \mathrm{M}$; nevertheless, a DIP concentration of $0.27 \mu \mathrm{M}$ remained in the surface layer in July (Table 1).

DOP did not show particular variations between the stations. Concentrations ranged between 0.31 and $0.20 \mu \mathrm{M}$ (Table 1) amounting to $33-100 \%$ of the total dissolved phosphorus pool. A spring to summer decline was probably caused by temperature. Surface DOP concentrations correlated inversely with the temperature (Spearman rank correlation: $p=0.008, n=13$ ) (Table 2), indicating that the DOP consumption may be enhanced with increasing temperature, compared to its production.

In the eastern Gotland Basin (Stn 271), chl a concentrations increased from post-spring bloom to summer, reaching maximum values of $14.79 \mu \mathrm{g} \mathrm{l}^{-1}$ in the first half of July. It remained on the same level of about $1.4 \mu \mathrm{g} \mathrm{l}^{-1}$ at Stn 213. In the south-eastern Gotland Basin (Stn 259) chl a concentrations were similar in May and July (4.36 to $4.70 \mu \mathrm{g} \mathrm{l}^{-1}$ ) with an interim lessening to $1.96 \mu \mathrm{g} \mathrm{l}^{-1}$ in June.

Heterocystous cyanobacteria contributed to phytoplankton development until summer (Table 1). They reached the highest biomasses in the first half of July at Stn 271 (eastern Gotland Basin). With a ww of $4515 \mathrm{mg} \mathrm{m}^{-3}$ they constituted $60 \%$ of the total autotrophs. At Stn 259 in the southern Gotland Basin, the highest biomasses were observed in the second half of July, a time delay of $14 \mathrm{~d}$ compared to the eastern Gotland Basin. Despite the absolute ww of $1608 \mathrm{mg} \mathrm{m}^{-3}$ being lower, they comprised $67 \%$ of the autotrophs. In the Bornholm Basin, heterocystous cyanobacteria occurred in negligible concentrations during the whole investigation period, contributing to a maximum of only $8 \%$ of the total phytoplankton biomass. The development of heterotrophic bacteria seemed to be coupled with phytoplankton develop-

Table 2. Significance level of the Spearman rank correlation between different parameters of the collected water samples during the whole investigation period from May until July 2005. DOP $=$ dissolved organic phosphorus; DIP = dissolved inorganic phosphorus; $\mathrm{n}=$ no. of values; $\mathrm{n} . \mathrm{s}$. = not significant

\begin{tabular}{|lcc|}
\hline Parameters & $\mathrm{n}$ & $\mathrm{p}$ \\
\hline Temp - DOP & 13 & 0.0082 \\
Chl a - Cyanobacteria & 13 & 0.0027 \\
Chl a - Heterotrophic bacteria & 12 & 0.0045 \\
Chl a - DIP & 13 & 0.0006 \\
DOP - Cyanobacteria & 13 & 0.0310 \\
DOP - Heterotrophic bacteria & 12 & n.s. \\
DIP - Heterotrophic bacteria & 12 & 0.0367 \\
\hline
\end{tabular}


ment (Spearman rank correlation with chl a: $\mathrm{p}=$ $0.0045, \mathrm{n}=12$ ) showing an increase from May to July. As can be deduced from the Spearman rank correlation between DIP concentrations and chl a and bacterial abundances, phytoplankton biomass influenced the DIP decline more strongly ( $p=0.0006)$ (Table 2) than did the heterotrophic bacteria $(p=0.0367)$. However, no relationship was found between the 2 organism groups and DOP concentrations in surface water.

\section{Verification of the BAP concentrations}

BAP concentrations with the addition of nitrogen and carbon could be detected in 11 of 12 experiments. In one experiment in May (Stn 213), DOP increased instead of decreasing. Here, apparently, the surplus DIP was consumed and converted into DOP and the BAP pool could not be detected with the method used (time course experiments).

In 2005, both BAP and DOP were in the same range as measured in 2004 (Fig. 2), but the high values found in May 2004 were not reached. BAP concentrations (Fig. 2) ranged between 0.04 and $0.12 \mu \mathrm{M}$ and comprised between 33.2 and $60.0 \%$ of the total DOP. As in 2004, BAP increased with increasing DOP concentrations. Summarizing the values of both years, the relationship can be described by the equation: BAP = $(0.92 \times$ DOP $)-0.14$. Similarly to 2004 , no elevated BAP concentrations $(0.05$ to $0.07 \mu \mathrm{M})$ were detected during the occurrence of diazotrophic cyanobacteria in the first half of July.

The refractory DOP (Fig. 3) ranged between 0.12 and $0.18 \mu \mathrm{M}$ in 2005, and did not differ from those values obtained in the previous year. Therefore, despite variations, the conclusions can be confirmed: the fluctuations in the DOP pool are mainly caused by the variations of BAP.

The time course experiments using the cyanobacterium Nodularia harveijana as the DOP-consuming organism showed that the bioavailable and refractory amounts of DOP were in the same range as measured in the time course experiments with heterotrophic bacteria under substrate additions (Table 3 ). With this additional experimental approach, the results from the experiments with heterotrophic bacteria were corroborated and we can conclude that the BAP deduced from our experiments comprised the bioavailable DOP in total.

\section{Use of DIP and DOP by heterotrophic bacteria under in situ conditions}

The DIP (Fig. 4a-d) and the DOP uptake (Fig. 4e-h) of heterotrophic bacteria with and without substrate

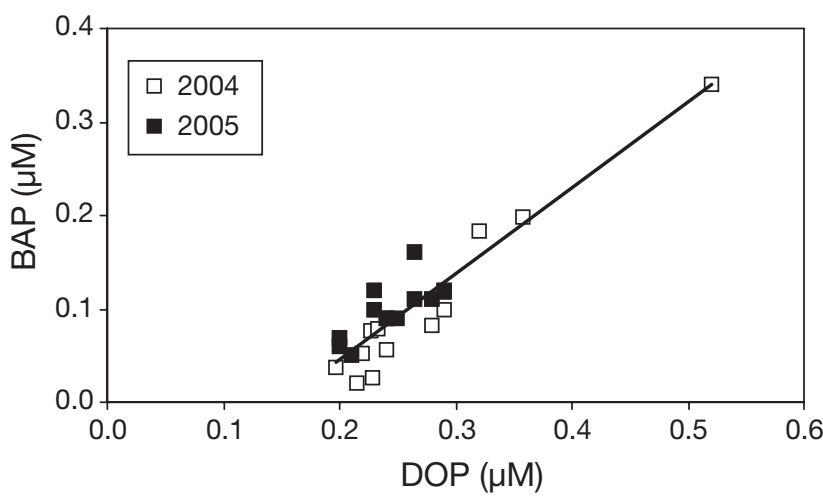

Fig. 2. Relationship between dissolved organic phosphorus (DOP) concentrations and bioavailable proportion (BAP) in surface water determined in experiments with additional carbon and nitrogen supply. Results obtained in 2005 are compared with those of 2004 . Regression line is calculated using the values of both years and is described by the equation $\mathrm{BAP}=(0.92 \times \mathrm{DOP})-0.14$

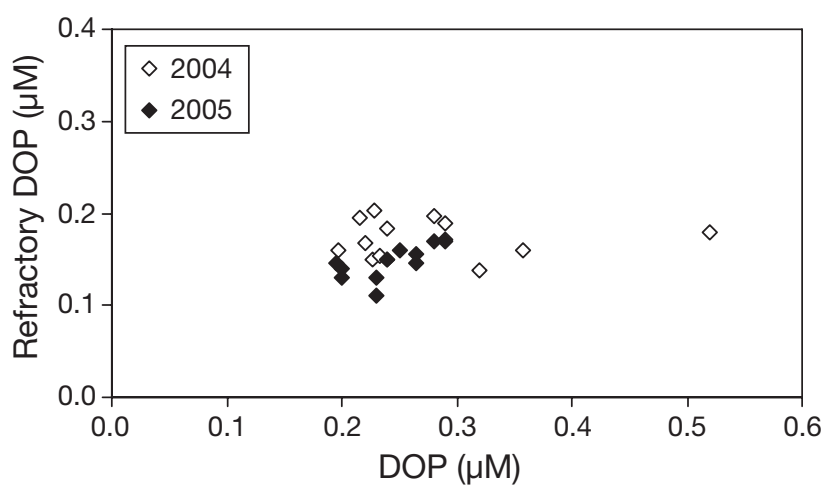

Fig. 3. Refractory dissolved organic phosphorus (DOP) concentrations in relation to DOP concentrations in surface water in 2004 and 2005

Table 3. Dissolved organic phosphorus (DOP) uptake (i.e. bioavailable phosphorus, BAP) by natural heterotrophic bacteria after carbon and nitrogen addition and by Nodularia harveijana

\begin{tabular}{|lcccc|}
\hline & $\begin{array}{c}\text { DOP at the } \\
\text { start of expt }(\mu \mathrm{M})\end{array}$ & $\begin{array}{c}\text { BAP detected using } \\
\text { heterotr. bacteria }(\mu \mathrm{M})\end{array}$ & $\begin{array}{c}\text { BAP detected using } \\
\text { N. harveijana }(\mu \mathrm{M})\end{array}$ & $\begin{array}{c}\text { Refractory } \\
\text { DOP }(\mu \mathrm{M})\end{array}$ \\
\hline May & 0.27 & 0.11 & 0.11 & 0.16 \\
June & 0.25 & 0.11 & 0.10 & 0.15 \\
July, 1st half & 0.16 & 0.06 & 0.05 & 0.11 \\
\hline
\end{tabular}



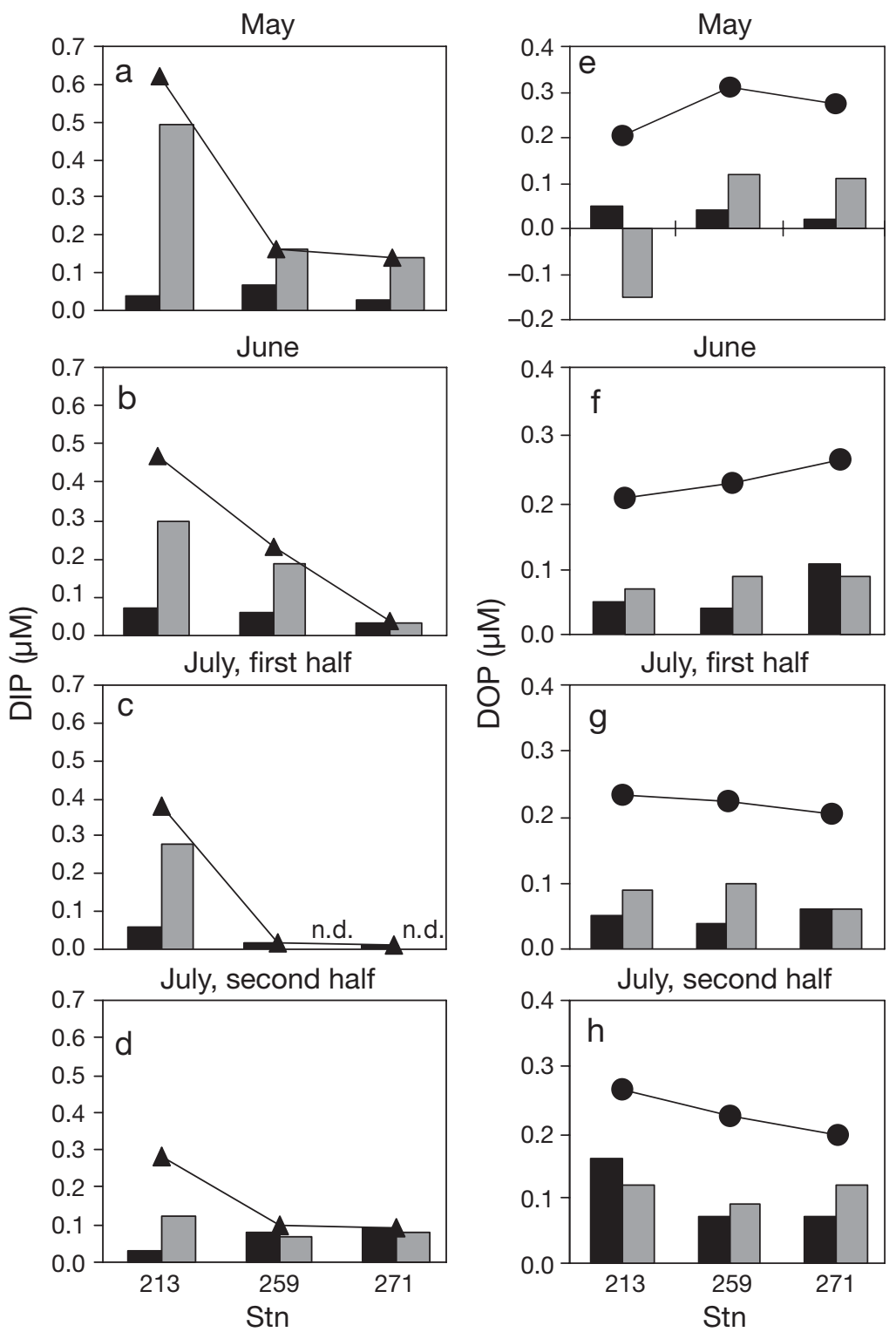

Fig. 4. Dissolved phosphorus concentrations in surface water and the consumption by heterotrophic bacteria in experiments with (grey bars) and without (black bars) carbon and nitrogen addition. (a-d) Dissolved inorganic phosphorus (DIP) concentrations and uptake; $(\mathrm{e}-\mathrm{h})$ dissolved or-

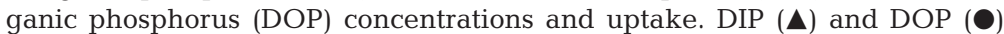
concentrations in original water. n.d. = not detected in original water (Panel c)

additions were compared. Both phosphorus species were used to a different degree under stimulated and non-stimulated (in situ) conditions and their uptake varied between the stations. DIP was consumed completely in substrate addition experiments in the southeastern and eastern Gotland Basin independently from the concentrations at the beginning of experiments. In contrast, it was consumed only partially in the experiments with surface water from Stn 213 in the Bornholm Basin during all 4 measuring campaigns. In that area, the initial DIP concentrations between 0.60 and $0.27 \mu \mathrm{M}$ were much higher than at the other stations. Nevertheless, DIP consumption of 0.50 to $0.12 \mu \mathrm{M}$ exceeded those of the other stations where consumed DIP ranged between 0.19 and $0.04 \mu \mathrm{M}$.

In the experiments without any substrate addition, considerably less DIP was used in May at all 3 stations (Fig. 4a). In June (Fig. 4b), the relatively low available amount of DIP at Stn 271 was taken up completely. The same held for Stns 259 and 271 during both investigation periods in July (Fig. 4c,d). In contrast, DIP uptake amounted to only a small proportion of DIP in the water at Stn 213 in the Bornholm Basin in July. Here, 84 to $94 \%$ of the initial DIP remained.

Comparing the DOP use in substrate addition experiments, representing complete BAP uptake, and the DOP use without any addition, representing in situ conditions, it is evident that BAP consumption by heterotrophic bacteria varied in time and space without a uniform pattern. In 8 of 12 experiments, BAP was not consumed completely. Heterotrophic bacteria took up between 18 and $78 \%$ of BAP corresponding to 7.3 and $35 \%$ of DOP. In 3 experiments, the BAP was all used $(100 \%)$.

The experiment in May, in the Bornholm Basin, could not be used for the calculation of BAP because DOP increased instead of decreasing. Generally, less BAP was used in May. With the transition to summer, use of DOP accelerated and was taken up more or less completely. It is remarkable that this tendency was also observed in the Bornholm Basin at Stn 213 where, in the second half of July, all the available BAP was taken up despite DIP not being consumed completely and $0.27 \mu \mathrm{M}$ remained.

During the time course experiments, bacterial growth occured. Bacterial abundances increased between $0.8 \times 10^{9}$ and $19.2 \times 10^{9}$ cells $^{-1}$ (Table $4 \mathrm{a}, \mathrm{b}$ ) corresponding to 13 and $123 \%$, respectively. The higher $\mathrm{P}$ consumption in substrate addition experiments did not induce strong growth (Fig. 5); rather, it resulted in a higher $\mathrm{P}$ content of $39.3 \mathrm{amol} \mathrm{cell}^{-1}$ (median value) in most of the cells (Table $4 \mathrm{~b}$ ) compared to $23.9 \mathrm{amol} \mathrm{cell}^{-1}$ (Table 4a) without substrate addition. 
Table 4. Dissolved organic phosphorus (DOP) and dissolved inorganic phosphorus (DIP) concentrations taken up by bacteria, increase of bacterial numbers and calculated uptake per bacterial cell (a) without and (b) with substrate additions. n.d. $=$ not done

\begin{tabular}{|c|c|c|c|c|c|c|}
\hline & Stn & $\begin{array}{l}\text { Phos } \\
\text { DIP } \\
(\mu \mathrm{M})\end{array}$ & $\begin{array}{l}\text { sphorus } \\
\text { DOP } \\
(\mu \mathrm{M})\end{array}$ & $\begin{array}{l}\text { s taken up } \\
\text { DIP + DOP } \\
(\mu \mathrm{M})\end{array}$ & $\begin{array}{c}\text { Increase of } \\
\text { bact. cells } \\
\left(\times 10^{9} \mathrm{l}^{-1}\right)\end{array}$ & $\begin{array}{c}\text { Total P } \\
\text { uptake } \\
\left(\text { amol cell }^{-1}\right)\end{array}$ \\
\hline \multicolumn{7}{|c|}{ (a) Without substrate additions } \\
\hline May & $\begin{array}{l}213 \\
259 \\
271\end{array}$ & $\begin{array}{l}0.04 \\
0.07 \\
0.03\end{array}$ & $\begin{array}{l}0.05 \\
0.04 \\
0.02\end{array}$ & $\begin{array}{l}0.09 \\
0.11 \\
0.05\end{array}$ & $\begin{array}{c}1.2 \\
13.4 \\
3.7\end{array}$ & $\begin{array}{c}73.5 \\
7.8 \\
13.6\end{array}$ \\
\hline June & $\begin{array}{l}213 \\
259 \\
271\end{array}$ & $\begin{array}{l}0.07 \\
0.06 \\
0.04\end{array}$ & $\begin{array}{l}0.05 \\
0.04 \\
0.11\end{array}$ & $\begin{array}{l}0.12 \\
0.10 \\
0.15\end{array}$ & $\begin{array}{l}5.6 \\
3.9 \\
3.1\end{array}$ & $\begin{array}{l}21.3 \\
25.6 \\
46.3\end{array}$ \\
\hline July, 1st half & $\begin{array}{l}213 \\
259 \\
271\end{array}$ & $\begin{array}{c}0.06 \\
0.02 \\
0.005\end{array}$ & $\begin{array}{l}0.05 \\
0.04 \\
0.06\end{array}$ & $\begin{array}{l}0.11 \\
0.06 \\
0.07\end{array}$ & $\begin{array}{l}3.6 \\
3.7 \\
2.9\end{array}$ & $\begin{array}{l}30.8 \\
16.2 \\
22.2\end{array}$ \\
\hline July, 2nd half & $\begin{array}{l}213 \\
259 \\
271\end{array}$ & $\begin{array}{l}0.03 \\
0.08 \\
0.09\end{array}$ & $\begin{array}{l}0.16 \\
0.07 \\
0.07\end{array}$ & $\begin{array}{l}0.19 \\
0.15 \\
0.16\end{array}$ & $\begin{array}{c}1.7 \\
19.2 \\
0.8\end{array}$ & $\begin{array}{c}113.7 \\
7.8 \\
198.4\end{array}$ \\
\hline $\begin{array}{l}\text { Mean } \\
\text { SD } \\
\text { Median }\end{array}$ & & & & $\begin{array}{l}0.11 \\
0.04 \\
0.11\end{array}$ & $\begin{array}{l}5.24 \\
5.48 \\
3.62\end{array}$ & $\begin{array}{l}48.11 \\
56.56 \\
23.90\end{array}$ \\
\hline \multicolumn{7}{|c|}{ (b) With substrate additions } \\
\hline May & $\begin{array}{l}213 \\
259 \\
271\end{array}$ & $\begin{array}{l}0.50 \\
0.16 \\
0.14\end{array}$ & $\begin{array}{l}\text { n.d. } \\
0.12 \\
0.11\end{array}$ & $\begin{array}{l}\text { n.d. } \\
0.28 \\
0.25\end{array}$ & $\begin{array}{c}9.4 \\
14.9 \\
5.4\end{array}$ & $\begin{array}{c}\text { n.d. } \\
18.85 \\
46.29\end{array}$ \\
\hline June & $\begin{array}{l}213 \\
259 \\
271\end{array}$ & $\begin{array}{l}0.30 \\
0.19 \\
0.04\end{array}$ & $\begin{array}{l}0.07 \\
0.09 \\
0.11\end{array}$ & $\begin{array}{l}0.37 \\
0.28 \\
0.15\end{array}$ & $\begin{array}{l}9.4 \\
8.3 \\
3.8\end{array}$ & $\begin{array}{l}39.35 \\
33.90 \\
37.79\end{array}$ \\
\hline July, 1st half & $\begin{array}{l}213 \\
259^{\mathrm{a}} \\
271^{\mathrm{a}}\end{array}$ & $\begin{array}{c}0.28 \\
0.14 \\
0.1\end{array}$ & $\begin{array}{c}0.09 \\
0.1 \\
0.06\end{array}$ & $\begin{array}{l}0.37 \\
0.24 \\
0.16\end{array}$ & $\begin{array}{l}8.6 \\
8.1 \\
4.4\end{array}$ & $\begin{array}{l}43.03 \\
29.56 \\
36.52\end{array}$ \\
\hline July, 2nd half & $\begin{array}{l}213 \\
259 \\
271\end{array}$ & $\begin{array}{l}0.12 \\
0.07 \\
0.08\end{array}$ & $\begin{array}{l}0.16 \\
0.09 \\
0.12\end{array}$ & $\begin{array}{l}0.28 \\
0.16 \\
0.20\end{array}$ & $\begin{array}{l}4.7 \\
3.3 \\
1.1\end{array}$ & $\begin{array}{c}60.34 \\
47.78 \\
182.03\end{array}$ \\
\hline $\begin{array}{l}\text { Mean } \\
\text { SD }\end{array}$ & & & & $\begin{array}{l}0.25 \\
0.08\end{array}$ & $\begin{array}{l}6.54 \\
3.40\end{array}$ & $\begin{array}{l}52.31 \\
11.20\end{array}$ \\
\hline Median & & & & 0.25 & 6.76 & 39.35 \\
\hline
\end{tabular}

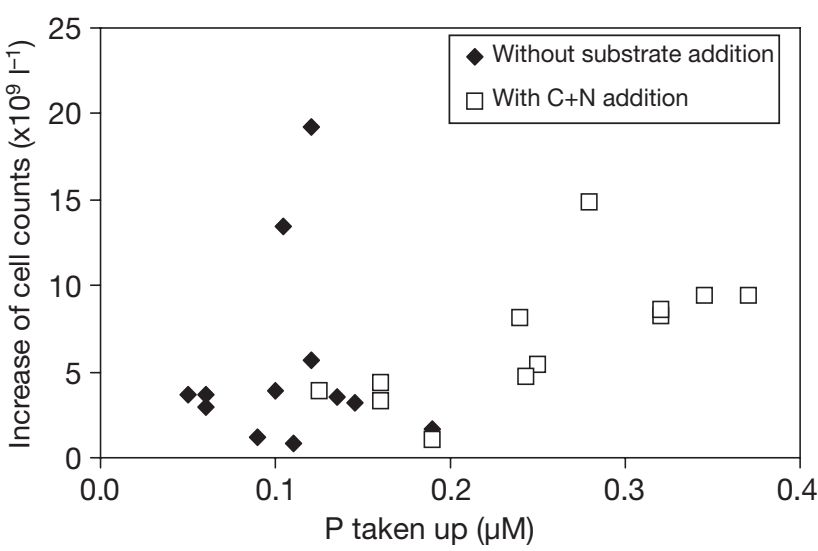

Fig. 5. Relationship between phosphorus uptake and bacterial growth in experiments with and without carbon and nitrogen addition

\section{DISCUSSION}

In general, it is accepted that DOP is a source for phosphorus nutrition for phyto- and bacterioplankton (Cotner \& Wetzel 1992, Karl \& Björkman 2002). However, its contribution to nutrition and consequently its significance is very difficult to appraise because only the bioavailable fraction can be used by the organisms. Therefore, there is an urgent need to quantify bioavailable DOP, but there are no suitable and generally accepted methods that allow extensive measurements of the BAP pool. The determination of BAP in time course experiments as done in our study is very time- and materialconsuming because it requires many sub-samplings and subsequent analyses. Therefore, this method does not allow extensive investigations of the BAP pool at numerous stations. Thus, we could determine the BAP pool and its use at only 3 stations in the central Baltic Sea during a 10 d cruise.

The advantage of this type of investigation is that information about BAP as a pool size is obtained assuming that the whole BAP pool can be detected (Nausch \& Nausch 2006). However, any indication of its biochemical characteristics is impossible. Another frequently used method to study the importance of DOP for bacteria comprises the uptake of added, single organic phosphorus compounds (Siuda \& Chrost 2001) or the inhibition of DIP uptake by single organic phosphorus compounds (e.g. Cotner \& Wetzel 1992, Björkman \& Karl 1994). The disadvantage of these approaches is that information about the BAP pool in total cannot be gathered.

Results from the present study agree well with the results obtained in the previous year (Nausch \& Nausch 2006). In both years, most DOP concentrations ranged between 0.20 and $0.32 \mu \mathrm{M}$, with a declining tendency from spring to summer probably due to elevated uptake compared to its release with increasing temperatures and DIP shortage. DOP concentrations exceeding this range can occur locally and temporally as detected in a spring bloom (Nausch \& Nausch 2006) and in cyanobacterial surface scums, when concentrations of up to $0.75 \mu \mathrm{M}$ were measured (Nausch et al. 2004). DOP concentrations obtained from our monitoring cruises in intervals of 2 mo convey relatively con- 
stant DOP concentrations of $0.19 \pm 0.06 \mu \mathrm{M}$ in the surface layer over the year $(2003 ; n=35)$. Assuming that DOP has been degraded within a short time of about 4 $\mathrm{d}$ as seen in our experiments, it would be very difficult to detect variations of in situ DOP concentrations even with a tight temporal resolution.

Comparing our results with those from the open ocean (Karl \& Björkman 2002, Suzumura \& Ingall 2004), it can be concluded that DOP concentrations are mostly within a similar range independent of whether conditions are oligotrophic or eutrophic. In the ocean, a clear gradient with depth to concentrations of around $0.10 \mu \mathrm{M}$ of refractory DOP was observed (Karl \& Björkman 2002), indicating that DOP is produced in the upper productive layer.

Similarly to 2004, the bioavailable fraction in 2005 constituted between 23.8 and $60.4 \%$ of total DOP. The residual DOP is assumed to be refractory DOP. This quantitative classification of DOP is supported by the experiments using Nodularia harveijana. N. harveijana used the same amount of DOP as heterotrophic bacteria after carbon and nitrogen amendment. In all experiments, BAP is that DOP used within 5 or $6 \mathrm{~d}$. It remains unknown if the residual refractory DOP cannot be used at all or if it needs longer to degrade.

To determine BAP using heterotrophic bacteria, carbon and nitrogen were added to avoid limitation by these elements. Neddermann \& Nausch (2004) showed that additional $\mathrm{C}$ and $\mathrm{N}$ supply induced an obvious phosphorus demand documented in an elevated alkaline phosphatase activity. Thus, the measured DOP taken up in substrate addition experiments was of potential value and the question arose as to what extent DOP or BAP was consumed by heterotrophic bacteria under natural water conditions. According to the present study, between 18 and $78 \%$ of the total BAP was consumed in most of the experiments without carbon and nitrogen addition. In some experiments, predominantly those conducted in summer, BAP was taken up completely. From the DIP and BAP availability as well as from the proportion of their uptake in the experiments without substrate additions, it can be deduced that the phosphorus uptake was C and/or N limited in the whole central Baltic Sea in May after the spring bloom. The limitation was reduced with the transition to summer in the eastern and south-eastern Gotland Basin, possibly by DOC and DON release when heterocystous cyanobacteria were abundant in high concentrations (Ohlendieck et al. 2000). There, C and $\mathrm{N}$ seem to be sufficient for the use of the whole DIP and BAP. It seems that BAP fulfils the P demand under this situation. Limitation of phosphorus use by dissolved organic $\mathrm{C}$ or other nutrients is mentioned by Cotner \& Wetzel (1992). They supposed that superior DOP use of bacteria in eutrophic lakes compared to oligotrophic lakes is caused by the greater availability of DOC in eutrophic lakes. Some of our own unpublished experiments show that both usable $\mathrm{C}$ and $\mathrm{N}$ have to be available in sufficient concentrations to stimulate alkaline phosphatase activity. The ratio between $\mathrm{C}$ and $\mathrm{N}$ was unimportant for phosphorus use by heterotrophic bacteria.

Another explanation for the DOP use is given by Hoppe \& Ullrich (1999) and Hansen \& Heath (2005). They stated that DOP can be used to fulfil the carbon demand instead of the phosphorus demand. Hoppe \& Ullrich (1999) deduced this from the high alkaline phosphatase activity in the presence of high DIP concentrations in the deep Atlantic Ocean. Hansen \& Heath (2005) found that the plankton community assimilated the C-moiety of ATP in P-rich hypolimnetic lake water whereas the P-moiety is preferred in epilimnic water. In our study, the function of DOP as a carbon source is likely in the Bornholm Basin in summer. Here, the BAP was also completely taken up despite DIP being sufficiently available. The added amount of $\mathrm{C}$ and $\mathrm{N}$ appears not to be sufficient to affect uptake of all the available DIP. Deduced from these results, C and/or $\mathrm{N}$ limitation occurred in the Bornholm Basin during the whole investigation period in 2005. Except the experiment in May at Stn 213, DIP and BAP has been transferred into bacterial biomass. In previous studies with nearshore water (Nausch \& Nausch 2004), DOP mineralization could be shown. In these experiments glycerophosphate was added as an additional organic phosphorus source to determine if the natural DOP is sufficient to fulfil the P demand. Glycerophosphate was not incorporated into bacteria without carbon and nitrogen amendment; it was released as DIP. However, in the presence of additional carbon and nitrogen, phosphorus from glycerophosphate was transferred into bacterial biomass, an indication that carbon and nitrogen induced a phosphorus demand whereas under in situ nutrient conditions the additional DOP is not necessary for bacterial growth.

The increase of DOP in May at Stn 213 can be seen as an indication that DOP can be produced actively by heterotrophic bacteria. The situation was characterized by extremely high DIP concentrations and possibly $\mathrm{C}$ and $\mathrm{N}$ limitation. Thus, bacteria are the mineralizers of DOP, as described in earlier studies (e.g. Cooper et al. 1991), and can be active DOP producers besides other known mechanisms such as cell death, phytoplankton exudation, or flagellate predation. DOP release by bacteria was earlier observed by Nausch \& Nausch (2004) at very low activities of alkaline phosphatase. Clark et al. (1999) showed that some bacterial cultures can produce phosphomonoesters and phosphonates. They found that these 2 components form the largest part of DOP in the oligotrophic Pacific. 


\section{LITERATURE CITED}

Benitez-Nelson CR, Buesseler KO (1999) Variability of inorganic and organic phosphorus turnover rates in the coastal ocean. Nature 398:502-505

Björkman K, Karl DM (1994) Bioavailability of inorganic and organic phosphorus compounds to natural assemblages of microorganisms in Hawaiian coastal waters. Mar Ecol Prog Ser 111:265-273

Björkman KM, Karl DM (2003) Bioavailability of dissolved organic phosphorus in the euphotic zone at station ALOHA, North subtropical gyre. Limnol Oceanogr 48:1049-1057

Chu SP (1946) The utilization of organic phosphorus by phytoplankton. J Mar Biol Assoc UK 26:285-295

Clark LL, Ingall ED, Benner R (1999) Marine organic phosphorus cycling: novel insights from nuclear magnetic resonance. Am J Sci 299:724-737

Cooper JE, Early J, Holding AJ (1991) Mineralization of dissolved organic phosphorus from a shallow eutrophic lake. Hydrobiologia 209:89-94

Cotner JB, Wetzel RG (1992) Uptake of dissolved inorganic and organic phosphorus compounds by phytoplankton and bacterioplankton. Limnol Oceanogr 37:232-243

DeFlaun MF, Paul JH, Jeffrey WH (1987) Distribution and molecular weight of dissolved DNA in subtropical estuarine and oceanic environments. Mar Ecol Prog Ser 38: 65-73

Dyhrman S, Chappell PD, Haley S, Moffett J, Orchard E, Waterbury J, Webb E (2006) Molecular evidence of phosphonate utilization in Trichodesmium. EOS Trans Am Geophys Union 87(suppl)

Gasol JM, del Giorgio PA (2000) Using flow cytometry for counting natural planktonic bacteria and understanding the structure of planktonic bacterial communities. Sci Mar 64:197-224

Grasshoff K, Ehrhardt M, Kremling K (1983) Methods of seawater analysis, 2nd edn. Verlag Chemie, Weinheim

Hansen DL, Heath RT (2005) Adenosine triphosphate (ATP) as a source of phosphorus and carbon to hypolimnetic and epilimnetic freshwater plankton communities in a stratified, hardwater lake. Ann Conf Great Lakes Res 48 [np]

Heath RT (1986) Dissolved organic phosphorus compounds: do they satisfy planktonic phosphate demand in summer? Can J Fish Aquat Sci 43:343-350

HELCOM (1980) Assessment of the effects of pollution on natural resources of the Baltic Sea. Balt Sea Environ Proc 5B:151-201

HELCOM (1988) Guidelines for the Baltic Sea Monitoring Programme for the third stage. Baltic Sea Environ Proc 27D:23-60

HELCOM (2001) Manual for marine monitoring in the COMBINE programme of HELCOM, Part C- Internet, updated 2001: www.helcom.fi/groups/Monas/Combine ManualAnnexesC/en GB/annex4/

Hoppe HG, Ullrich S (1999) Profiles of ectoenzymes in the Indian Ocean: phenomena of phosphatase activity in the mesopelagic zone. Aquat Microb Ecol 19:139-148

Johannes RE (1964) Uptake and release of dissolved organic phosphorus by representatives of a coastal marine ecosystem. Limnol Oceanogr 9:224-234

Kalle K (1932) Phosphatgehaltuntersuchungen in der Nordund Ostsee im Jahre 1931. Ann Hydrogr 60(1):6-17

Kalle K (1933) Phosphate und Gesamtphosphor in Beziehung zu Temperatur, Salzgehalt und Plankton an der Oberfläche der isländischen Küstengewässer. Ber Dtsch Wiss Komm Meeresforsch 6:273-299
Karl DM, Björkman K (2002) Dynamics of DOP. In: Hansell $\mathrm{AD}$, Carlson GA (eds) Biogeochemistry of marine dissolved organic matter. Academic Press, Amsterdam, p 250-366

Kolowith LC, Ingall ED, Benner R (2001) Composition and cycling of marine organic phosphorus. Limnol Oceanogr 46:309-320

Matsuda O, Ohmi K, Sasada K (1985) Dissolved organic phosphorus in sea water, its molecular weight fractionation and availability to phytoplankton. J Fac Appl Biol Sci Hiroshima Univ 24:33-42

Minear RA (1972) Characterization of naturally occurring dissolved organophosphorus compounds. Environ Sci Technol 6:431-437

Monaghan EJ, Ruttenberg KC (1999) Dissolved organic phosphorus in the coastal ocean: reassessment of available methods and seasonal phosphorus profiles from Eel River Shelf. Limnol Oceanogr 44:1702-1714

Nausch G, Feistel R, Lass HU, Nagel K, Siegel H (2005) Hydrographisch-chemische Zustandseinschätzung der Ostsee 2004. Meereswiss Ber Warnemuende 62:1-78

Nausch G, Feistel R, Lass HU, Nagel K, Siegel H (2006) Hydrographisch-chemische Zustandseinschätzung der Ostsee 2005. Meereswiss Ber Warnemuende 66:1-82

Nausch M, Nausch G (2004) Bacterial utilization of phosphorus pools after nitrogen and carbon amendment and its relation to alkaline phosphatase activity. Aquat Microb Ecol 37:237-245

Nausch M, Nausch G (2006) Bioavailability of dissolved organic phosphorus in the Baltic Sea. Mar Ecol Prog Ser 321:9-17

Nausch M, Nausch G, Wasmund N (2004) Phosphorus dynamics during the transition from nitrogen to phosphate limitation in the central Baltic Sea. Mar Ecol Prog Ser 266: $15-25$

Neddermann K, Nausch M (2004) The seasonality of stimulation of alkaline phosphatase activity by organic and inorganic nitrogen. Aquat Ecol 38:475-484

Nehring D, Brügmann L (1977) Die Verteilung organischer Phosphor- und Stickstoffverbindungen in der Ostsee. Acta Hydrochim Hydrobiol 5:533-539

Newcombe CL, Brust HF (1940) Variations in the phosphorus content of estuarine waters of the Chesapeake Bay near Solomons Island, Maryland. J Mar Res 33:76-88

Ohlendieck U, Stuhr A, Siegmund H (2000) Nitrogen fixation by diazotrophic cyanobacteria in the Baltic Sea and transfer of the newly fixed nitrogen to pikoplankton organisms. J Mar Syst 25:213-219

Põder T, Maestrini SY, Balode M, Lips U, Béchemin C, Andrushaitis A, Purina I (2003) The role of inorganic and organic nutrients on the development of phytoplankton along a transect from the Daugava River mouth to the open Baltic in spring and summer 1999. ICES J Mar Sci 60:827-835

Robinson RJ (1941) Perchloric acid oxidation of organic phosphorus in lake waters. Ind Eng Chem Anal Ed 13: 465-466

Sannigrahi P, Ingall ED, Benner R (2006) Nature and dynamics of phosphorus-containing components of marine dissolved and particulate organic matter. Geochim Cosmochim Acta 70:5868-5882

Siuda W, Chrost RJ (2001) Utilization of selected dissolved organic phosphorus compounds by bacteria in lake water under non-limiting orthophosphate conditions. Pol J Environ Stud 10:475-483

Stepanauskas R, Jørgensen NOG, Eigard OR, Žvikas A, Tranvik LJ, Leonardson L (2002) Summer inputs of riverine 
nutrients to the Baltic Sea: bioavailibility and eutrophication relevance. Ecol Monogr 72:579-597

Strickland JDH, Solorzano L (1966) Determination of monoesterase hydrolysable phosphate and phosphomonoesterase activity in sea water. In Barnes H (ed) Some contemporary studies in marine science. George Allen Unwin, London, p 665-674

Suzumura M, Ingall ED (2004) Distribution and dynamics of various forms of phosphorus in seawater: insights from

Editorial responsibility: Otto Kinne (Editor-in-Chief), Oldendorf/Luhe, Germany field observations in the Pacific Ocean and a laboratory experiment. Deep-Sea Res I 51:1113-1130

Wattenberg H, Meyer H (1936) Der jahreszeitliche Gang des Gehaltes des Meerwassers an Planktonnährstoffen in der Kieler Bucht im Jahre 1935. Kiel Meeresforsch 1: 264-278

Yoshimura T, Nishioka J, Saito H, Takeda S, Tsuda A, Wells ML (2007) Distributions of particulate and dissolved organic and inorganic phosphorus in North Pacific surface waters. Mar Chem 103:112-121

Submitted: September 14, 2007; Accepted: October 8, 2007 Proofs received from author(s): November 26, 2007 